\title{
Bioefficacy of Rumen-Protected Methionine in Improving Nitrogen Deposition in Goats
}

\author{
Tatsuo Muramatsu, Takayuki Hatano, Mitsuhiro Furuse \\ and Jun-ichi OKumura \\ School of Agriculture, Nagoya University, \\ Chikusa-ku, Nagoya-shi 464-01
}

(Received Junc 6, 1991)

Key words : Bioefficacy, Rumen-protected methionine, Nitrogen deposition, Goats

In ruminants, methionine may frequently be a most-limiting amino acid in diets ${ }^{\text {? }}$. Although estimation of amino acid requirements is of considerable difficulty due to the presence of the rumen in ruminants, the general needs for methionine has been substantiated by abomasal infusion of this amino acid, resulting in improved $\mathrm{N}$ deposition and growth performance ${ }^{10}$. For supplying deficient amino acids, however, the abomasal infusion is not a convenient method in practice. Alternative approach has recently been developed by using various methionine preparations known as rumen-protected methionine (RPM) that is resistant to degradation in the rumen. The resistance can be attained by coating amino acids with fat and chitosan, or by making amino acid polymers.

Previously, it was shown that dietary RPM supplement improved $\mathrm{N}$ deposition and enhanced whole-body protein synthesis in goats". The effect of RPM was also indicated in goats fed a diet based on either urea hay cube or wheat bran-hay cube as major $N$ sources". Thus, under certain circumstances RPM is useful in promoting ruminant performance. However, to what extent the use of RPM preparation is beneficial compared with methionine per se is not well known. In the present study, therefore, the bioefficacy of RPM relative to methionine in improving $N$ deposition in the goat was investigated.

\section{Materials and Methods}

Five female Japanese Saanen goats at 15 to 17 months of age, weighing 35 to $52 \mathrm{~kg}$, were used. During an adaptation period for 7 days, they were given a basal diet containing wheat bran hay cube with a small amout of soybean oil, supplying $1.3 \mathrm{gN}$ and $0.15 \mathrm{Mcal} \mathrm{DE} / \mathrm{kg}^{0.75}$ per day, to meet requirements according to $\mathrm{NRC}^{6}$. Extra mineral was provided with a mineral block (Koen, Nihon Zenyaku Co., Fukushima) which contained $(/ \mathrm{kg}) ; \mathrm{NaCl}$, $995.5 \mathrm{~g} ; \mathrm{ZnSO}_{4}, 1235 \mathrm{mg} ; \mathrm{MnCl}_{2}, 1146 \mathrm{mg}$; $\mathrm{Fe}_{2} \mathrm{O}_{3}, 715 \mathrm{mg}$; $\mathrm{CuSO}_{4}, 377 \mathrm{mg}$; KI, $65.5 \mathrm{mg}$; $\mathrm{CoSO}_{4}, 6.6 \mathrm{mg}$. The goats were then transferred to metabolism cages, and given the same diet once a day at 10:00 for further 35 days, consisting of 5 treatment periods. Water was

ヤギの空素蓄皘量改善におけるルーメン保護メチオニンの生物的効力：村松迋夫・幡野貴之・古瀨尤厷・奥村純 市 (名古屋大学宸学部 名古屋市下喠区 464-01)

Anim. Sci. Technol. (Jpn.) 62 (12) : 1153-1155 1153 
provided daily at 2-3 liters per goat. The dietary treatments were as follows (g/goat per day) : no supplement (conrrol); DL-methionine, 4.5 ; DL-methionine, 9.0 ; bead RPM (Lactet ${ }^{*}$ containing $30 \%$ DL-methionine, Nihon Soda Co. Ltd., Tokyo), 5 ; pellet RPM (a variant of the Lactet preparation containing $30 \%$ DL-methionine, Nihon Soda Co. Ltd., Tokyo), 5. Unlike the total $\mathrm{N}$ and DE intake, levels of the dietary supplements were not adjusted for metabolic body weight. However, because of a small variation in metabolic body weights among goats $\left(16.6 \pm 0.9(\mathrm{SE}) \mathrm{kg}^{0.75}\right.$ ), the effect of unadjustment was deemed small. Goats were assigned to these treatments according to $5 \times 5$ Latin-Square design. In each treatment period for 7 days, the last 3 days were used for collection of urine and feces to allow the measurement of $\mathrm{N}$ deposition. The $\mathrm{N}$ content in the diet, urine and feces was determined by a Kjeldahl method.

Analysis of variance was done to treat the data statistically, and regression of $\mathrm{N}$ deposition on amounts of methionine intake was done using GLM procedure ${ }^{9}$.

\section{Results and Discussion}

Changes in $\mathrm{N}$ deposition by feeding various methionine supplements are shown in Fig. 1, indicating clearly that DL-methionine increased $\mathrm{N}$ deposition in a linear fashion within the range tested, and that the two RPM also improved $\mathrm{N}$ deposition in goats. These results are in good agreement with the previous findings ${ }^{3,4}$. Using the methionine intake ranging from $0,4.5$ and $9 \mathrm{~g}$ /goat per day, a regression equation was obtained as : $\mathrm{Y}=0.406+$ $0.023 \mathrm{X}(\mathrm{r}=0.56, \mathrm{P}<0.05)$ where $\mathrm{Y}$ and $\mathrm{X}$ are $\mathrm{N}$ deposition ( $\mathrm{g} / \mathrm{kg}^{0.75}$ per day) and amount of methionine intake ( $\mathrm{g} / \mathrm{day}$ ). The regression equation revealed that the bioefficacy of RPM in improving $\mathrm{N}$ deposition was approximately 4.6 times (bead RPM) and 2.5 times (pellet RPM) as high as that of methionine per se. The true reason for the difference in the

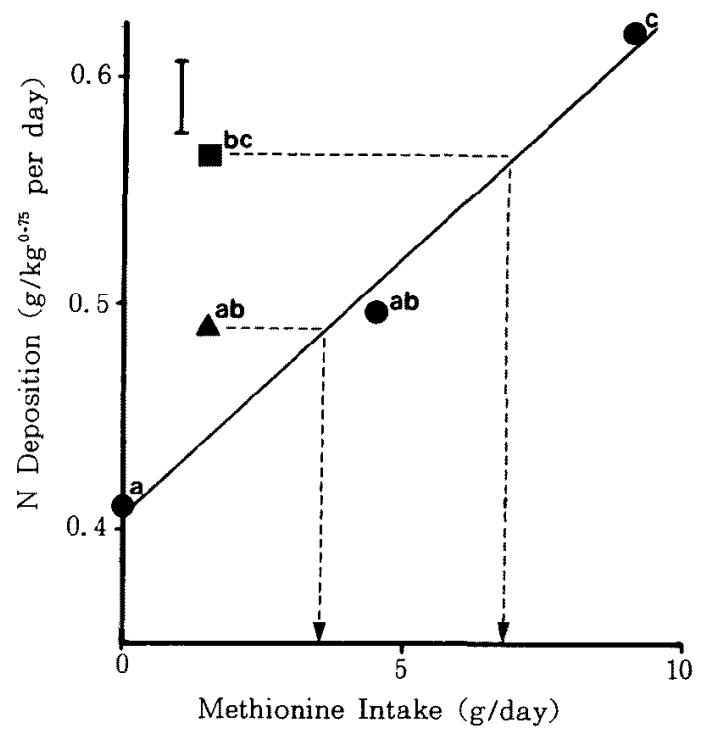

Fig. 1. Effect of supplementing with methionine (O) or rumen-protected methionine $(\boldsymbol{a}$, bead; $\boldsymbol{\Lambda}$, pellet) on $\mathrm{N}$ deposition in goats fed a wheat bran-hay cube diet. All methionine supplements were administered as a DL-form. The regression equation of $\mathrm{N}$ deposition on DL-methionine intake at $0,4.5$ and $9 \mathrm{~g} /$ goat per day was obtained as: $\mathrm{Y}=$ $0.406+0.023 X(r=0.56, P<0.05)$. Two rumenprotected methionine preparations were fed orally at $1.5 \mathrm{~g}$ DL-methionine/goat per day. Values are means of 5 goats, and the vertical bar stands for a pooled SEM. a,b,c Symbols not sharing a common superscript letter are significantly different at $\mathrm{P}<0.05$. Arrows stand for estimated methionine equivalents for each RPM preparation.

extent of improvement in $\mathrm{N}$ deposition between the two RPM preparations was unknown.

Although methionine was reported to be relatively resistant to rumen degradation among amino acids ${ }^{1,3}$, most of the methionine added to the diet was degraded to release ammonia, and therefore unavalilable to the host goat. Assuming that bypass rates of amino acids are similar between sheep and goats, and that methionine equivalence of the two RPM preparations is $6.9 \mathrm{~g}$ for bead RPM and $3.75 \mathrm{~g}$ for pellet RPM as indicated from 
the regression equation, the results of COTTLE and VELLE ${ }^{3)}$ with sheep experiments suggest that amounts of methionine which could have escaped from the degradation in the rumen, and thereby reached the lower gut to be absorbed would be approximately $490 \mathrm{mg}$ and $1200 \mathrm{mg}$ for pellet RPM and bead RPM respectively, resulting in the corresponding apparent bypass rates being 33 and $80 \%$.

It should be born in mind, however, that the bioefficacy of RPM may well be varied under certain nutritional and physiological circumstances because the diet dependency of effects of rumen-protected amino acids on milk production has been reported in dairy $\operatorname{cows}^{2,8}$. Indeed, in goats the effect of enhancing $\mathrm{N}$ deposition was no longer apparent when fed a diet high in crude protein (unpublished). Further studies remain to be done before a firm conclusion can be drawn whether the finding in the present study could be limited to a specific dictary condition or it could be applied rather generally to a variety of circumstances.

\section{Acknowledgment}

Rumen-protected methionine preparations were donated by Nihon Soda Co. Ltd., Tokyo, Japan.

\section{References}

1) Chalupa, W. Digestion of amino acids by the mixed rumen microbial population. $J$.
Anim. Sci., 43: 828-834. 1976.

2) Chow, J.M., E.J. DePeters and R.L. BALDWIN, Effect of rumen protected methionine and lysine on casein in milk when diets high in fat or concentrate are fed. J. Dairy Sci., 73 : 1051-1061. 1990.

3) Cotrle, D.J. and W. Velle, Degradation and outflow of amino acids from the rumen of sheep. Br. J. Nutr., 61: 397-408. 1989.

4) Muramatsu, T., T. Hatano, Y. Ueda, M. Furuse and J. OKumura, Effect of rumenprotected methionine on whole-body protein synthesis in goats. Asian-Australasian J. Anim. Sci., 2: 247-248. 1989.

5) Muramatsu, T., T. Hatano, Y. Ueda, M. Furuse and J. Okumura, Enhanced wholebody protein turnover in goats fed a diet supplemented with rumen protected methionine. J. Anim. Sci., 68 (S1) : 515-516 (Abstr.). 1990.

6) National Research Council, Nutrient requirements of goats. 10-12. National Academy Press. Washington, D.C.. 1981.

7) Richardson, C.R. and E.E. Hatfield, The limiting amino acids in growing cattle. J. Anim. Sci., 46 : 740-745. 1978.

8) Rogers, J.A., S.B. Pierce-Sandner and A.M. PAPAS, Production responses of daily cows fed various amounts of rumenprotected methionine and lysine. J. Dairy Sci., $72:$ 1800-1817. 1989.

9) SAS, SAS User's Guide: Statistics. SAS Institute Inc. Cary. NC. U.S.A. 1985.

10) Schelling, G.T., J.E. Chanderer and G.C. Scotr, Postruminal supplemental methionine infusion to sheep fed high quality diets. J. Anim. Sci., 37 : 1034-1039. 1973. 